\title{
Distribution of pathogens causing nosocomial infection in patients with bronchial asthma
}

\author{
W. Mao and E.H. Cui \\ Department of Respiration, Huzhou Central Hospital, Huzhou, Zhejiang Province, \\ China \\ Corresponding author: W. Mao \\ E-mail: enhaicui@163.com
}

Genet. Mol. Res. 14 (4): 16146-16150 (2015)

Received August 4, 2015

Accepted October 11, 2015

Published December 8, 2015

DOI http://dx.doi.org/10.4238/2015.December.8.3

ABSTRACT. This study aimed to analyze nosocomial respiratory infection (NRI) in patients with bronchial asthma. Among the clinical data of 575 asthmatic patients that was collected and analyzed, 52 were diagnosed with NRI. The most common gram-positive bacterial species was Streptococcus pneumoniae, which was detected in 8 patients, whereas the predominant Gram-negative bacteria included Haemophilus influenzae (11 patients), Moraxella catarrhalis (8 patients), and Escherichia coli (7 patients). The simultaneous detection of all strains was predominant in patients older than 65 years of age, whereas the detection rates of $S$. pneumoniae, $H$. influenzae, E. coli, and $M$. catarrhalis were predominant in patients younger than 65 years old. The differences in the detection rates were not significant between the male and female groups. From this study, we can conclude that S. pneumoniae, H. influenzae, E. coli, and $M$. catarrhalis are common NRI-causing pathogens, and bacterial infection is the main risk factor for NRI in asthmatic patients.

Key words: Bronchial asthma; Distribution of pathogens; Nosocomial infection 


\section{INTRODUCTION}

Bacterial infection is considered the main risk factor for nosocomial respiratory infection (NRI) in asthmatic patients (Eder et al., 2006; Bisgaard et al., 2007; Hauk et al., 2008; Marra et al., 2009; Bisgaard et al., 2010) but its mechanism remains unclear. Otero et al. (2013) reported that bacterial infection may elicit the imbalanced expression of T helper cells types 1 and 2 (Koch et al., 2007). Peroni et al. (2010) analyzed the pathogen distribution in elderly asthmatic patients and revealed that asthma was induced by the ecological imbalance of pathogenic microbes, which was confirmed by an animal experiment study by Piacentini et al. (2010). Current research has revealed that bacterial infection-induced asthma involves bacterial heat shock proteins, which may compromise the human immune system and induce asthma. This conclusion has been corroborated by the results of subsequent experiments involving antimicrobial treatments. In addition, bacterial infection induces inflammation and cytokines produced by $\mathrm{T}$ helper cells, which can induce airway hyperresponsiveness and asthma. Other studies (Ortiz-Stern et al., 2011; Okamoto et al., 2012) have demonstrated that bacterial lipopolysaccharides can promote the growth of mucosal dendritic cells that are important to the immune response. Furthermore, several research centers in the United States have found that Chlamydia or Mycoplasma pneumoniae can induce asthma; however, these data warrant further confirmation (Grayston et al., 1990; Emre et al., 1995; Von Hertzen et al., 1996). Therefore, the treatment of asthma should be conducted concomitantly with the control and prevention of NRI.

\section{Material and methods}

\section{General data}

A total of 575 patients with acute asthma, including 309 men and 266 women between the ages of 42 and 85 years, were recruited from the Department of Respiratory Medicine in Huzhou Central Hospital (China) between January 2008 and January 2011. This study was conducted in accordance with the declaration of Helsinki. This study was conducted with approval from the Ethics Committee of Huzhou Central Hospital, and written informed consent was obtained from all participants.

\section{Sample collection and bacterial identification}

Oropharyngeal and nasopharyngeal secretions of patients were collected, and a disposable sputum suction tube was inserted into the lower respiratory tract to collect sputum for future bacterial identification. The bacterial strains were cultured on Müller-Hinton agar; susceptibility paper disks and petri dishes were purchased from Oxoid (United Kingdom). Bacterial strains were isolated and identified according to conventional microbiological tests using a VITEK 32 automatic analyzer from Bio-Merieux (France). The colonies of the unidentified bacterial strains were stained after isolation and examined under an optical microscope. Oxidase and catalase tests were performed on gram-negative and gram-positive bacteria, respectively.

\section{Statistical analysis}

Data were analyzed with the SPSS16.0 (IBM, Chicago, IL, USA) software. Comparison between groups was performed using the chi-square test, and the significance level was set at $P<0.05$. 


\section{RESULTS}

\section{Pathogen distribution}

Among the 52 pathogen strains identified, 12 bacterial strains $(23.07 \%)$ were gram-positive and 38 bacterial strains (73.07\%) were gram-negative. In addition, 2 fungal strains were identified, representing $3.8 \%$ of the pathogenic strains (Table 1 ).

\section{Table 1. Constituent ratios (\%) of the pathogens causing NRI in asthmatic patients.}

\begin{tabular}{lrr}
\hline Pathogen & Strain & Constituent ratio \\
\hline Gram-positive bacteria & 12 & 23.08 \\
Streptococcus pneumoniae & 8 & 15.39 \\
Staphylococcus aureus & 2 & 3.85 \\
Staphylococcus epidermidis & 1 & 1.92 \\
Enterococcus & 1 & 1.92 \\
Gram-negative bacteria & 38 & 73.07 \\
Haemophilus influenzae & 11 & 21.15 \\
Moraxella catarrhalis & 8 & 15.39 \\
Escherichia coli & 7 & 13.46 \\
Klebsiella pneumoniae & 6 & 11.54 \\
Enterobacter cloacae & 3 & 5.76 \\
Pseudomonas aeruginosa & 2 & 3.85 \\
Acinetobacter baumannii & 1 & 1.92 \\
Fungus & 2 & 3.85 \\
Candida albicans & 1 & 1.93 \\
Candida krusei & 1 & 1.92 \\
Total & 52 & 100.0 \\
\hline
\end{tabular}

\section{Association between pathogen distribution and patient age and sex}

Among the 52 patients with NRI, 28 were men and 24 were women. Regarding age, 25 patients were younger than 65 and 27 patients were older than 65 . The differences in the detection rates were not significant between the male and female groups; however, they reached statistical significance in patients older than 65 years of age $\left(X^{2}=7.519, P<0.05\right.$; Table 2$)$.

Table 2. Constituent ratios of the pathogens in different genders of patients at various ages (\%).

\begin{tabular}{|c|c|c|c|c|c|c|}
\hline & & $\begin{array}{c}\text { Gram-positive bacteria }(\mathrm{N}=12) \\
\text { Strain Constituent Ratio }\end{array}$ & $\begin{array}{c}\text { Gram-negative bacteria }(\mathrm{N}=38) \\
\text { Strain Constituent Ratio }\end{array}$ & $\begin{array}{c}\text { Fungus }(\mathrm{N}=2) \\
\text { Strain Constituent Ratio }\end{array}$ & $x^{2}$ value & $P$ value \\
\hline Age & $>65$ & $83.83(10)$ & $34.21(13)$ & $100.00(2)$ & 7.519 & 0.132 \\
\hline (years) & $\leq 65$ & $16.67(2)$ & $65.79(25)$ & $0.00(0)$ & & \\
\hline \multirow[t]{2}{*}{ Gender } & Male & $58.33(7)$ & $52.63(20)$ & $50.00(1)$ & 0.132 & 0.936 \\
\hline & Female & $41.67(5)$ & $47.37(18)$ & $0.00(1)$ & & \\
\hline
\end{tabular}

\section{DISCUSSION}

Recently, the association between bacterial infection and asthma has gained attention in the field of medicine. Many studies have confirmed that bacterial endotoxins can cause airway hyperresponsiveness and trigger asthma, likely due to bacterial endotoxins promoting an increase in the permeability of tracheal mucosal epithelial cells. Bacterial lipopolysaccharides can also stimulate the immune response as antigens disturb the balance between immune cell subtypes and induce asthma (Zhu et al., 2010). Moreover, it has been noted that the respiratory system of indi- 
viduals with asthma contains more proteobacteria, and bacterial colonization occurs earlier than that in non-asthmatics (Huffnagle, 2010; Marri et al., 2013). Some studies conducted early in the twentieth century revealed that respiratory infection correlated with asthma, but most scholars disagree with this conclusion. At present, the mechanism of asthma induced by bacterial infection is contradicted both nationally and internationally. However, bacterial respiratory infections reportedly allow pathogens and allergens to stimulate the production of specific antibodies, which can remain attached to the respiratory mucosa, cause allergic reactions through the presence of allergens, and induce asthma (Fernández-Benítez, 2001). In addition, bacterial respiratory infections can damage airway epithelial cells and increase their permeability, with the subsequent release of inflammatory mediators, and induce asthma (Talbot et al., 2005; Edwards et al., 2012; Habibzay et al., 2012).

In addition, some researchers observed that $C$. pneumoniae can induce asthma (Horvat et al., 2010a, 2010b; Starkey et al., 2012). It has been reported (Jahnsen et al., 2006; Ahmed et al., 2007; Goleva et al., 2008) that NRI-induced asthma may be associated with neural regulatory mechanisms. The researchers define a bacterial infection to be when epithelial cells are injured and the stimulated sensory receptors of damaged cells induce spasms and cough, thereby triggering airway hyperresponsiveness and asthma.

Fifty-two patients were diagnosed with NRI among 575 asthmatic patients (infection rate of $9.04 \%)$. Most NRI-causing bacteria in asthmatic patients were gram-negative, including 11 strains of Haemophilus influenzae, 8 strains of Moraxella catarrhalis, and 7 strains of Escherichia coli. The total detection rate was predominant in patients older than 65 years, whereas the detection rates of Streptococcus pneumoniae, $H$. influenzae, E. coli, and $M$. catarrhalis were predominant in patients younger than 65 years. The differences in the detection rates were not significant between the male and female groups; however, these differences reached statistical significance in patients older than $65\left(X^{2}=7.519, P=0.023\right)$. These results were similar to those obtained in the study by Nagayama et al. (2001).

Therefore, we conclude that bacterial infection is the main risk factor for NRI in patients with bronchial asthma (Eder et al., 2006; Bisgaard et al., 2007; Hauk et al., 2008; Marra et al., 2009; Bisgaard et al., 2010). For this reason, the treatment of asthma should be conducted in association with the control and prevention of NRI. Once NRI is detected, pathogenic strains should be immediately identified and adequately controlled.

\section{Conflicts of interest}

The authors declare no conflict of interest.

\section{ACKNOWLEDGMENTS}

Research supported by the Zhejiang Province Welfare Technology Applied Research Program (\#2011C33051) and the Zhejiang Province Appropriate Technology Applied Research Program(\#2014ZHB006).

\section{REFERENCES}

Ahmed S, Macfarlane GT, Fite A, McBain AJ, et al. (2007). Mucosa-associated bacterial diversity in relation to human terminal ileum and colonic biopsy samples. Appl. Environ. Microbiol. 73: 7435-7442.

Bisgaard H, Hermansen MN, Buchvald F, Loland L, et al. (2007). Childhood asthma after bacterial colonization of the airway in neonates. N. Engl. J. Med. 357: 1487-1495. 
Bisgaard H, Hermansen MN, Bønnelykke K, Stokholm J, et al. (2010). Association of bacteria and viruses with wheezy episodes in young children: prospective nested birth cohort study. BMJ. 341: c4978.

Eder W, Ege MJ and von Mutius E (2006). The asthma epidemic. N. Engl. J. Med. 355: 2226-2235.

Edwards MR, Bartlett NW, Hussell T, Openshaw P, et al. (2012). The microbiology of asthma. Nat. Rev. Microbiol. 10: $459-471$.

Emre U, Sokolovskaya N, Roblin PM, Schachter J, et al. (1995). Detection of anti-Chlamydia pneumoniae IgE in children with reactive airway disease. J. Infec. Dis. 172: 265-267.

Fernández-Benítez M (2001). The role of infection in asthma. Allergol. Immunopathol. 29: 147-151.

Goleva E, Hauk PJ, Hall CF, Liu AH, et al. (2008). Corticosteroid-resistant asthma is associated with classical antimicrobial activation of airway macrophages. J. Allergy Clin. Immunol. 122: 550-559.

Grayston JT, Campbell LA, Kuo CC, Mordhorst CH, et al. (1990). A new respiratory tract pathogen: Chlamydia pneumoniae strain TWAR. J. Infect. Dis. 161: 618-625.

Habibzay M, Saldana JI, Goulding J, Lloyd CM, et al. (2012). Altered regulation of Toll-like receptor responses impairs antibacterial immunity in the allergic lung. Mucosal Immunol. 5: 524-534.

Hauk PJ, Krawiec M, Murphy J, Boguniewicz J, et al. (2008). Neutrophilic airway inflammation and association with bacterial lipopolysaccharide in children with asthma and wheezing. Pediatr. Pulmonol. 43: 916-923.

Horvat JC, Starkey MR, Kim RY, Beagley KW, et al. (2010a). Chlamydial respiratory infection during allergen sensitization drives neutrophilic allergic airways disease. J. Immunol. 184: 4159-4169.

Horvat JC, Starkey MR, Kim RY, Phipps S, et al. (2010b). Early-life chlamydial lung infection enhances allergic airways disease through age-dependent differences in immunopathology. J. Allergy Clin. Immunol. 125: 617-625, 625.e1-625.e6.

Huffnagle GB (2010). The microbiota and allergies/asthma. PLoS Pathog. 6: e1000549.

Jahnsen FL, Strickland DH, Thomas JA, Tobagus IT, et al. (2006). Accelerated antigen sampling and transport by airway mucosal dendritic cells following in halation of a bacterial stimulus. J. Immunol. 177: 5861-5867.

Koch A, Knobloch J, Dammhayn C, Raidl M, et al. (2007). Effect of bacterial endotoxin LPS on expression of INF-gamma and IL-5 in T-lymphocytes from asthmatics. Clin. Immunol. 125: 194-204.

Marra F, Marra CA, Richardson K, Lynd LD, et al. (2009). Antibiotic use in children is associated with increased risk of asthma. Pediatrics 123: 1003-1010.

Marri PR, Stern DA, Wright AL, Billheimer D, et al. (2013). Asthma-associated differences in microbial composition of induced sputum. J. Allergy Clin. Immunol. 131: 346-352, e1-e3.

Nagayama Y, Tsubaki T, Toba T, Nakayama S, et al. (2001). Analysis of sputum taken from wheezy and asthmatic infants and children, with special reference to respiratory infections. Pediatr. Allergy Immunol. 12: 318-326.

Okamoto M, Takeda K, Lucas JJ, Joetham A, et al. (2012). Low-dose lipopolysaccharide affects lung allergic responses by regulating Jagged1 expression on antigen-pulsed dendritic cells. Int. Arch. Allergy Immunol. 157: 65-72.

Ortiz-Stern A, Kanda A, Mionnet C, Cazareth J, et al. (2011). Langerin+ dendritic cells are responsible for LPS-induced reactivation of allergen-specific Th2 responses in postasthmatic mice. Mucosal Immunol. 4: 343-353.

Otero C, Paz RD, Galassi N, Bezrodnik L, et al. (2013). Immune response to Streptococcus pneumoniae in asthma patients: comparison between stable situation and exacerbation. Clin. Exp. Immunol. 173: 92-101.

Peroni DG, Pietrobelli A and Boner AL (2010). Asthma and obesity in childhood: on the road ahead. Int. J. Obes. 34: 599-605.

Piacentini GL, Peroni DG, Bonafiglia E, Chinellato I, et al. (2010). Childhood asthma control test (C-CAT) and nasal eosinophil inflammation in asthmatic children. Allergy 65: 796-797.

Starkey MR, Kim RY, Beckett EL, Schilter HC, et al. (2012). Chlamydia muridarum lung infection in infants alters hematopoietic cells to promote allergic airway disease in mice. PLoS One 7: e42588.

Talbot TR, Hartert TV, Mitchel E, Halasa NB, et al. (2005). Asthma as a risk factor for invasive pneumococcal disease. N. Engl. J. Med. 352: 2082-2090.

Von Hertzen L, Lsoaho R, Leinonen M, Koskinen R, et al. (1996). Chlamydia pneumoniae antibodies in chronic obstructive pulmonary disease. Int. J. Epidemiol. 25: 658-664.

Zhu Z, Oh SY, Zheng T and Kim YK (2010). Immunomodulating effects of endotoxin in mouse models of allergic asthma. Clin. Exp. Allergy 40: 536-546. 